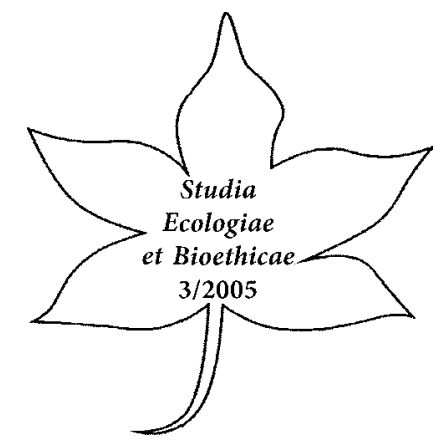

\title{
Ksiądz Petro Verhun - historia pewnego życia i śmierci
}

\begin{abstract}
I
Kościół greckokatolicki (zwany też unickim, czy Ukraińskim Kościołem Katolickim $^{1}$ ) powstał w efekcie unii zawartej między Rzymem a częścią kościoła prawosławnego Rzeczypospolitej Obojga Narodów (1596 r.). Prawosławni, którzy odżegnywali się od przyjęcia unii uznali jej postanowienia za niezgodne z prawem i na przestrzeni wielu wieków sprzeciwiali się idei kościoła greckokatolickiego. Egzystencji „nowego” kościoła nie ułatwiał także dystans i niechęć duchownych rzymskokatolickich żywiona do przedstawicieli hierarchii unickiej. Po rozbiorach Polski unia została zlikwidowana na terenie Ukrainy prawobrzeżnej i na Chełmszczyźnie, które znalazły się w orbicie wpływów Rosji prawosławnej. Natomiast w austriackiej Galicji - ukraińskim Piemoncie - kościół unicki rozwijał się swobodnie stając się z czasem symbolem niepodległych dążeń Ukraińców. Po II wojnie światowej władza komunistyczna ustosunkowała się negatywnie do grekokatolików. W 1946 roku na tzw. synodzie lwowskim włączyła oficjalne struktury kościoła greckokatolickiego do cerkwi prawosławnej, a duchownych poddała eksterminacji i zsyłkom na Syberię. ${ }^{2}$ Jej działalność mogła być kontynuowana tylko na emigracji, szczególnie zaś w USA i Niemczech.
\end{abstract}

1 Pierwszą używana nazwą byl „kościół unicki“ (ten, który przyjąl unię). Maria Teresa chcąc podnieść jego status wprowadza w 1774 roku nazwę "greckokatolicki", ponieważ w obliczu sytuacji kryzysowej, w której znalazł się kościól, określenia „unita“, „unicki“ nabierają pejoratywnego znaczenia. Nazwę Ukraiński Kościół Katolicki wprowadza Josyf Slipyj po przyjeździe do Rzymu z zesłania. Od 1991 roku funkcjonuje ona w Europie Zachodniej i USA.

2 Z zesłania udało się powrócić ukraińskiemu duchownemu arcybiskupowi Lwowa Josipowi Slipyjowi (1963), który w pewnym sensie został „podarowany" papieżowi Janowi XXIII w dowód sympatii i uznania za interwencję Watykanu i załagodzenie konfliktu wokół procederu dostarczania sowieckich rakiet na Kubę, co groziło wybuchem wojny z USA. 


\section{II}

Historia kościoła greckokatolickiego w Niemczech rozpoczyna się wraz z działalnością misyjną ukraińskich księży sprawujących opiekę duszpasterską nad robotnikami sezonowymi głównie z Królestwa Galicji i Lodomerii. ${ }^{3} \mathrm{~W}$ tym czasie wielu Ukraińców żyje w pobliżu górnośląskich kopalń, w miastach portowych (Hamburg, Brema) oraz ich okolicach (Hemelingen czy Delmenhorst). W portach prócz robotników sezonowych zatrzymują się także Ukraińcy udający się na emigrację do USA, Brazylii i Kanady.

$Z$ upływem czasu, wraz z rosnącą ilością ukraińskich emigrantów i robotników sezonowych metropolia lwowska postanawia stworzyć w Niemczech kościelną administrację, która nadałaby pracy duszpasterskiej bardziej formalny kształt. Pierwszym stałym proboszczem oddelegowanym przez metropolitę Andrzeja Szeptyckiego w 1907 roku był ks. Oleksij Baziuk. Po nim nastąpili: Leontij Kunycki, Wołodymyr Hanicki, Mychajło Kindij. ${ }^{4}$ 8.11.1927 do Berlina wyjeżdża Petro Werhun, który otrzymuje święcenia kapłańskie bezpośrednio $\mathrm{z}$ rąk metropolity Andrzeja Szeptyckiego. Od tego momentu historia kościoła greckokatolickiego w Niemczech aż do 1945 roku będzie związana z jego wielostronną działalnością.

Petro Werhun ${ }^{5}$ urodził się 18.11.1890 roku w Gródku Jagiellońskim, w Galicji, jako syn stolarza Iwana i Pelagii z domu Rusyn. W ojczyźnie zakończył szkołę ludową i średnią, w której otrzymał świadectwo maturalne. W 1909 roku zgłosił się na ochotnika do cesarskiego pułku piechoty $\mathrm{nr} 89 \mathrm{w}$ Jarosławiu. W czasie wojny został ranny koło Zaleszczan $\left(19.10 .1914\right.$ roku ${ }^{6}$, a po upadku monarchii habsburskiej wstąpił jako żołnierz do Ukraińskiej Armii Halickiej (UHA), gdzie zaprzyjaźnił się z późniejszym wikariuszem generalnym rezydującym w Monachium, Petrem Hołynśkym. ${ }^{7}$ Nieco później przystąpił do ukraińskiej brygady górskiej w Rosenthal. ${ }^{8} \mathrm{~W}$ Czechosłowacji włącza się w podziemną

3 Petro Romanyszyn, Ukrajina i Nimeczczyna, Monachium 1978, s. 13-17, Zyła Wołodymyr, Apostolśkyj Ekzarchat u Nimeczczyni i Skandynawiji, Monachium 1989, s. 30-32

4 Bernadetta Wótowicz, Zarys dziejów Ukraińskiego Kościoła Katolickiego w Niemczech, w: Biuletyn Ukrainoznawczy, Przemyśl 2001, nr 7, s. 78.

5 Archiwum Kloster Nideraltaich, Personalakten Praelaten Dr Peter Verhun, Apostol. Administrator der Ukrainer in Deutschland, oblate Fr. Pachomius, curriculum vitae Lebenslauf, Anharskyj Poasełok, 24.03.1956. Por. Petro Romanyszyn, Ukrajinśka Katolyćka Cerkva, s.11-14, Dmytro Zlepko, Die ukrainische griechisch-katholische Visitatur in Berlin 1940-1945, w: Naukowyj Zbirnyk, T.X, Monachium, 1983, s.432-434.

- Archiwum Apostolskiego Egzarchatu dla Ukraińców Katolików (dalej jako Arch.AE), Korespondencija pomiż W.Preosw.Buczkom i o.Pralatom Petrom Holynśkym 1955-1959, list Werhuna do Panny dr., Anharskyj Posełok, 14.04.1956.

7 Ebenda, Hołynśkyj do Buczka, Monachium, 7.05.1956.

8 Polityczne życie Ukraińców po I wojnie światowej przenosi się na emigrację, głównie zaś do Niemiec, Austrii i Czechosłowacji. Było to efektem napiętych stosunków polsko-ukraińskich 
działalność Ukraińskiej Organizacji Wojskowej (UWO - Ukrajinśka Wijskowa Orhanizacija $)^{9}$. Po tym, jak rząd czeski zezwala Ukraińcom na kontynuowanie nauki (wrzesień 1920) Werhun zapisuje się na studia teologiczne w Uniwersytecie Karola (Universita Karlova), po czym zostaje przyjęty jako alumn do katolickiego seminarium w Pradze. Broni doktorat z historii kościoła i 4.01.1927 zostaje oddelegowany przez Szeptyckiego do Berlina w celu kontynuacji studiów z historii sztuki oraz pracy nad rozprawą habilitacyjną. Zostaje jednak jeszcze we Lwowie (od lutego do listopada 1927), gdzie 30.10 otrzymuje świecenia kapłańskie. Do Berlina dociera jesienią 1927 i obejmuje opieką duszpasterską wszystkich katolickich Ukraińców w Niemczech.

Początki nie były łatwe. Werhun borykał się z brakiem księży, a większość obowiązków w diecezji berlińskiej spadała na jego barki. Na początku 1943 roku sytuacja zmusiła go nawet do likwidacji stanowiska kanclerza Wizytatury Apostolskiej. Duchownego, który piastował ten urząd zatrudnił jako duszpasterza świeckiego. O swej ówczesnej wielostronnej pracy Werhun pisze do papieża: „Niżej podpisany podróżuje, wizytuje i celebruje, gdzie tylko się da. Najczéściej podróżuje sam i odprawia msze święte przeważnie $w$ regionach, w których nie ma żadnych księży" ${ }^{10}$

Werhun zajmuje się nie tylko roztaczaniem opieki duchowej nad wiernymi, ale stara się także o utrzymanie dobrych kontaktów z rzymskokatolickim kościołem w Niemczech. Podróżuje po kraju wyglaszając dla wiernych, księży i teologów niemieckich wykłady o kościele wschodnim. Oddaje się pracy na niwie naukowej. W Uniwersytecie berlińskim piastuje stanowisko asystenta ds. historii kościołów wschodnich. W piśmie Germania zamieszcza serię artykułów o Ukraińskim Kościele Katolickim, jest autorem dwóch studiów poświęconych kościołom wschodniego obrządku i podtrzymuje żywe kontakty z organizacją Catolica Unio. ${ }^{11}$ Ponadto wspiera finansowo studentów ukraińskich nie bacząc na ich wyznanie (katolickie czy prawosławne), a także uczestniczy aktywnie w powołaniu Ukraińskiego Instytutu Naukowego w Berlinie. ${ }^{12}$

będących skutkiem wojny o Zachodnią Ukrainę trwającej od 1.11.1918 przez następne dziewięć miesięcy. W wojnie tej zginęlo 10 tysięcy Polaków i 15 tysięcy Ukraińców. Pamięć o niej kladła się cieniem na stosunkach polsko-ukraińskich przez cały okres międzywojenny. Por. Wladysław A. Serczyk, Historia Ukrainy, Ossolineum, Wrocław-Warszawa-Kraków, 2001, s.285.

- Ukraińska Organizacja Wojskowa została założona w Pradze 30.08.1920 r. Prowadzila działalność konspiracyjną, przygotowywała akcje terrorystyczne w celu wywołania interwencji dyplomatycznej państw zachodnich i reaktywowania Ukraińskiej Republiki Ludowej. Na jej bazie utworzono w roku 1929 na kongresie w Wiedniu Organizację Ukraińskich Nacjonalistów (OUN), która współpracowała z rządem niemieckim. Por. Serczyk, ebenda, s.302.

10 Arch. OSMB - Rzym, Werhun do Papieża, Pismo nr 289/44, Berlin 16.6.1944, s.5.

11 Zlepko, op.cit., s. 432-433.

12 Ukraiński Instytut Naukowy został założony w Berlinie w 1926 roku przez grupę wybitnych emigrantów ukraińskich i niemieckich naukowców. Współpracownicy Instytutu przenieśli 
Po otrzymaniu święceń kapłańskich Werhun postanowia zdystansować się do polityki i zrywa kontakty z UWO. Jego krótka przynależność do tej organizacji nie pozostała jednak bez skutków. W 1935 roku odbywa się tzw. „proces warszawski” wymierzony przeciwko Organizacji Ukraińskich Nacjonalistów. Rząd polski żąda wydalenia Ukraińców przebywających na terenie Rzeszy. Tylko dzięlki interwencji ówczesnego nuncjusza w Niemczech, późniejszego papieża Piusa XII, Eugenio Paccelego, Werhun może zostać w Berlinie. ${ }^{13}$ Jednak nie do końca udaje mu się uniknąć konsekwencji wcześniejszej działalności politycznej. W 1938 roku w Polsce uchwalona zostaje ustawa, zgodnie z którą wszyscy obywatele polscy przebywający od co najmniej pięciu lat za granicą, albo też biorący udział w akcjach wymierzonych przeciwko Polsce tracą polskie obywatelstwo. Dotyczyło to również Werhuna, który mimo licznych interwencji Ordynariatu w Berlinie, nie uzyskuje przedłużenia ważności paszportu. ${ }^{14}$

Dr Werhun od początku działalności bezwzględnie zwalcza nastroje komunistyczne szerzące się wśród ukraińskich robotników w Niemczech. ${ }^{15}$ Nie najlepiej układają się także jego stosunki $z$ radykalnymi ukraińskimi nacjonalistami. W jednym z listów do nuncjusza apostolskiego Orsenigo pisze:

„Walki z komunistami, a ostatnio te $\dot{z} z$ nacjonalistami ( $z$ ostatnimi zawartem rozejm 26.5.1941 roku, obiecali wspótpracować z kościotem i przestrzegać jego rozporządzeń) nie byly tatwe". ${ }^{16}$

Już podczas wielu podróży służbowych po Niemczech Werhun nawiązuje przyjazne kontakty z klasztorem benedyktyńskim w Niederaltaich koło Passau. Sympatie, którymi darzył opactwo wynikały stąd, że mnisi tej reguły nie pozostawali obojętni na sprawy kościoła wschodniego ${ }^{17}$ (był to m.in. efekt zadania nałożonego na nich przez papieża Piusa XI: mieli oni dążyć do wzmocnienia kon-

się po drugiej wojnie światowej do Monachium, bowiem w amerykańskiej strefie okupacyjnej posiadali większy zakres wolności ułatwiajacej im dalszą działalność. Por. Główne Bawarskie Archiwum Państwowe (dalej zwane GBAP), Sygn. MKV-193, Staatsministerium fuer Unterricht und Kultus, Auslaederschulen in Bayern - UFU, Bd.I, 1947-1948, The Ukrainian Scientific Institut of Berlin at Present Leipzig, nr 22463. Por. też : Carsten Kumke, Das Ukrainische Wissenschaftliche Institut. Zwischen Wissenschaft und Politik, w: JGO 43, 1995, s. 218-253.

13 Zlepko, op.cit., s.433.

14 Arch. AE, Riżny akty peredani pislja smerty o.Pralata Hołynśkoho, s.3 (dokument bez szczegółowego opisu).

15 Ebenda, s.4.

16 Arch. OSBM, Rzym, Werhun do Orsenigo, 31.5.1941, s.2.

17 Klasztory benedyktyńskie od początku żywiły sympatię do obrządku wschodniego. Na przykład benedyktyni w północnej Dalmacji (Chorwacja) sprzyjali rozprzestrzenianiu się rytu słowiańskiego i sami odprawiali msze zgodnie z tą liturgią. Nawet dzisiaj można znaleźć tam inskrypcje głagolickie. Por. Leonard Górka (ks.), Swięci Cyryl i Metody a pojednanie, Warszawa, Lublin, 2001. W samym klasztorze Niederaltaich do dzisiaj istnieje kaplica urządzona zgodnie z wymogami kościoła wschodniego, w której mnisi odprawiają liturgie w języku staro-cerkiewno-słowiańskim. 
taktów z kościołami wschodnimi: greckokatolickim i prawosławnym. ${ }^{18}$ ) Werhun w 1938 roku składa na ręce opata Emmanuela Heufeldera uroczyste przyrzeczenie i stając się oblatem ${ }^{19}$ przyjmuje imię Pachomius. Od tego czasu jego celem jest możliwie szybkie wstąpienie w progi zakonu, co planuje uczynić po znalezieniu następcy. Nagły wybuch II wojny światowej przekreśla jednak te plany.

\section{III}

22.06.1945 roku Werhun zostaje aresztowany przez NKWD, po czym pod zarzutem „kolaboracji z wrogiem” skazany przez sowiecki trybunał wojskowy na osiem lat robót przymusowych i zesłany do obozu karnego Tajszet (niedaleko Jeziora Bajkał). W 1953 roku zostaje osiedlony w wiosce syberyjskiej Angarskij Posełok w krasnojarskim kraju.

Przyjaciele i współpracownicy Werhuna przyjmują jego nieoczekiwane zesłanie z głębokim smutkiem, wręcz oszołomieniem. Osobista sekretarka ukraińskiego duszpasterza Maria Werner pisze do księdza Romanyszyna:

„O Ekscelencji nic mi nie wiadomo. Ta skrajna niepewność jest okropnym stanem $i$ im dlużej trwa, tym trudniej ja znieść. Niedlugo od tego bólu i zmartwienia nie pozostanie ze mnie nawet cień. (...) Nawet najgorsza wiadomość bylaby lepsza od tej skrajnej niepewności. Biskup Berlina rozmawial rzekomo w tej sprawie $z$ Amerykanami, i jak mówi Biskup Wienken, byt także u Rosjan, którzy mieli powiedzić, że w niedtugim czasie otrzymamy jakieś wieści o Dr Werhunie. Ale do dzisiaj nie dotarła do nas żadna informacja, i nie wierze $w$ to, że dotrze." 20

Pierwsze wiadomości od Werhuna docierają do klasztoru Niederaltaich dopiero w 1956 roku. W liście prosi klasztor o pomoc i umożliwienie, jako byłemu obywatelowi austriackiemu, powrotu do Niemiec (Deutschösterreich):

„Mam nadzieję, że otrzymam pozwolenie na wyjazd do Niemiec, głównie ze wzgledu na to, że od momentu przyjścia na świat aż do czasu upadku monarchii Habsburgów bylem poddanym austriackim i podczas pokoju, jak $i$ w stanie wojny 1914/1918 slużylem $w$ armii austriackiej. 19.10.1914 zostałem nawet ranny. Teraz jestem pozbawiony obywatelstwa. Po przyjeździe chcialbym dokończyć żywota w klasztornej samotności, w benedyktyńskim klasztorze, na prowincji, w górskiej okolicy."21

W celu otrzymania pozwolenia na wyjazd ze ZSSR Werhun zmuszony był przedłożyć dokument stwierdzający gotowość przyjęcia do zgromadzenia zakon-

18 Emmanuel Heufelder, Fuer Christi Reich im Osten, s. 31.

19 Członek katolickiego zgromadzenia zakonnego, w którym nie składa się ślubów, tylko przyrzeczenie wytrwania, (lac. oblatus - ofiarowany).

20 Werner do Romanyszyna, 7.01.1946, w: Romanyszyn, Ukrajinśka Katolyćka Cerkwa, s. 108.

21 Arch.Kloster Niederaltaich, Werhun do Przeora Bonifacego, 24.03.1956. 
nego. Zaświadczenie takie musiało być wystawione przez klasztor w Austrii, jako że sprawa dotyczyła obywatela austriackiego. W tym celu opat klasztoru w Niederaltaich zaangażował $\mathrm{w}$ całą sprawę opactwo benedyktyńskie $\mathrm{z}$ Wiednia.

Pierwszy znak życia otrzymany od Werhuna obudził wśród jego niemieckich i ukraińskich przyjaciół nowe nadzieje. 19.04.1956 roku na zebraniu kapituły członkowie konwentu jak i opat opowiedzieli się jednogłośnie za przyjęciem Werhuna w progi swego klasztoru. W celu przyspieszenia wszelkich formalności opat Bonnifaz Pfister udał się do Wiednia (20.04.1956), gdzie spotkał się z przełożonym opactwa Schotten, by uzyskać konieczną obietnicę przyjęcia Werhuna oraz uzyskania od władz austriackich pozwolenia na jego wjazd. Po otrzymaniu wymaganych dokumentów Bonifaz skontaktował się z sekretarzem stanu ministerstwa spraw wewnętrznych Dr Grafem, który za pośrednictwem ministerstwa spraw zagranicznych obiecał zwrócić się w tej sprawie do ambasady austriackiej w Moskwie.

Klasztor Niederaltaich podjął także kontakty z niemieckimi i polskimi wspólpracownikami Werhuna. Ówczesny greckokatolicki wikariusz generalny w Monachium, Petro Hołynśkyj, pisał do opata Heufeldera, że hierarchia ukraińskiego kościoła przez długie lata uważała Werhuna za zmarłego, bowiem nie docierały od niej jakiekolwiek wiadomości. Dopiero w 1953 roku Ukraiński Kościół Katolicki otrzymał po raz pierwszy informację, że Werhun żyje. Bardziej szczególowe wieści dotarły w 1955 roku od pewnego Ukraińca, dr Knjażynśkiego, który zetknął się z Werhunem na Syberii. ${ }^{22}$

Opat Heufelder nie omieszkał także zwrócić się z prośbą o pomoc do Kościelnej Służby Poszukującej Zaginionych (kirchlicher Suchdienst). Służba radziła nie wysyłać żadnych paczek, czy listów bezpośrednio z Niederaltaich, jak tylko za pośrednictwem austriackiego opactwa. ${ }^{23}$ Od tego momentu całą korespondecję z Niederaltaich i innych klasztorów kierowano do Werhuna za pośrednictwem przeora opactwa Schotten (Wiedeń) Piusa Bölmanna. ${ }^{24}$

10.07.1956 roku Werhun otrzymuje od austriackiego ministerstwa spraw wewnętrznych pozwolenie na wjazd, w którym jednak brak jakiejkolwiek wzmianki o jego obywatstwie austriackim. ${ }^{25}$ Co gorsza, wciąż nie było optymistycznych wieści o losie Werhuna od tych, którzy opuścili Syberię na prawach nowoogło-

22 Arch. Kloster Niederaltaich, Hołynśkyj do Heufeldera, Monachium, 12.05.1956.

23 Arch. Kloster Niederaltaich, Kirchlicher Suchdienst, Ref. Zivilverszleppte an Heufelder, Passau, 3.05.1956, 7.05.1956.

24 Arch. Kloster Niederaltaich, Pfister do Bölmanna, Niederaltaich, 19.05.1956. O.Pius pisał: „Na wszelki wypadek napisałem jeszcze raz do prałata Werhuna kartkę po rosyjsku, żeby wiedzial, że otrzymaliśmy jego korespondencję, i że będziemy robić co tylko w naszej mocy, aby go wyzwolić."

25 Arch. Niederaltaich, Bundesministerium fur Inneres, Einwanderungserlaubnis (Odpis), nr 96.350-12/56, 10.07.1956. 
szonej amnestii. Pewien Polak z Warszawy, Wienczysław Jędrzejewski, przebywający z Werhunem na Syberii w latach 1952-1956 pisze do przeora Klasztoru Niederaltaich:

„Abstrahując od tego, że brak jest jakichkolwiek prawnych podstaw do tego, by przypisać Werhunowi obywatelstwo sowieckie, to i tak organy odpowiedzialne robiq co wich mocy, by nie dopuścić do jego wyjazdu z USSR. Mija już drugi rok, od kiedy powinien zostać zwolniony z zestania na prawie ogloszonej amnestii i (...) powinien otrzymać tzw. „Zaświadczenie o pobycie dla osób bez obywatelstwa” (...). Jednak czynniki rzadowe z jakichś powodów czynia wszystko, żeby wcisnać mu sowiecki paszport. W momencie, kiedy go przyjmie zniszczy wszystkie swe nadzieje na spokojnq starość w klasztorze. (...) Uczynit wszystko co byto możliwe - teraz pozostaje mu tylko nadzieja w Bogu. Przy pożegnaniu prosit mnie, abym po głębszym zastanowieniu poradził Panu jak rozwiąać jego sprawę. Ale jak?". ${ }^{26}$

Początkowo sądzono, że to władze austriackie przyczyniły się do tego stanu rzeczy odmawiając Werhunowi przyznania obywatelstwa. Dlatego też przeor Bonifaz zwraca się do przełożonego opactwa Schotten z prośbą, by jak najszybciej wystarał się u rządu austriackiego o odpowiedni dokument. Jednocześnie podejmuje kontakt z Rzymem i instytucjami niemieckimi, a także zapytuje przeora Schotten, czy do „wyrwania” Werhuna z Syberii mogłyby przyczynić się jakieś wyższe austriackie instytucje lub Austriacki Czerwony Krzyż. ${ }^{27}$

Po pewnym czasie wyjaśnia się, że obywatelstwo austriackie nie jest żadną przepustką do rozwiązania sprawy Werhuna, bowiem i tak nie zostałoby zaakceptowane przez Rosjan, którzy w takich przypadkach wymagali od petenta czteroletniego pobytu na terytorium Austrii (po 1945 roku). Przyjaciele Werhuna zaczynają w końcu rozumieć, iż żadne naciski i starania nie są w stanie przyspieszyć jego powrotu z Syberii, a wszystko zależy tylko i wyłącznie od dobrej woli rządu sowieskiego. Ojciec Bölmann pisze o tym w swoim liście:

„Gródek koło Lwowa (miejsce urodzenia Werhuna) należy dzisiaj do Rosji, w związku z czym Dr Werhun wtaściwie posiada sowieckie obywatelstwo, którego ważność nie wygaśnie nawet wtedy, jeśli otrzyma obywatelstwo austriackie. Wszystko zależy tylko od Rosjan, czy zechca go wypuścić, czy też nie. (...) Jeśli zechca, to zrobia to także bez austriackiego obywatelstwa". 28

Ojciec Pfister nie rezygnuje i nawiązuje kontakty z Austriackim Czerwonym Krzyżem, który obiecuje zwrócić się do Sowieckiego Czerwonego Krzyża, by wywarł nacisk na odpowiednie czynniki rządowe. ${ }^{29} \mathrm{~W}$ tym samym czasie jed-

26 Arch. Kloster Niederaltaich, Wienczysław Jędrzejewski an Prior Bonifaz, Waszawa 1956.

27 Arch. Kloster Niederaltaich, Bundesministerium fuer Inneres, Einwanderungserlaubnis (odpis), nr 96.350-12/56, 10.07.1956.

28 Arch. Kloster Niederaltaich, Bölmann do Pfistera, Wiedeń, 20.02.1957.

29 Arch. Kloster Niederaltaich, Austriacki Czerwony Krzyz do opactwa Niederaltaich, Salzburg, 26.03.1957. 
nak docierają do klasztoru Niederaltaich pierwsze, jeszcze niepewne, wzmianki o śmierci Werhuna, które ostatecznie zostały potwierdzone nadesłanymi z pogrzebu fotografiami i oficjalną informacją śmierci. ${ }^{30}$

Największe marzenie Werhuna, by dożyć końca dni w klasztorze Niederaltaich nie spełniło się. Umarł w Angarskim Posiolku po operacji 7.02.1957 roku - głównym powodem śmierci było krańcowe wycieńczenie organizmu.

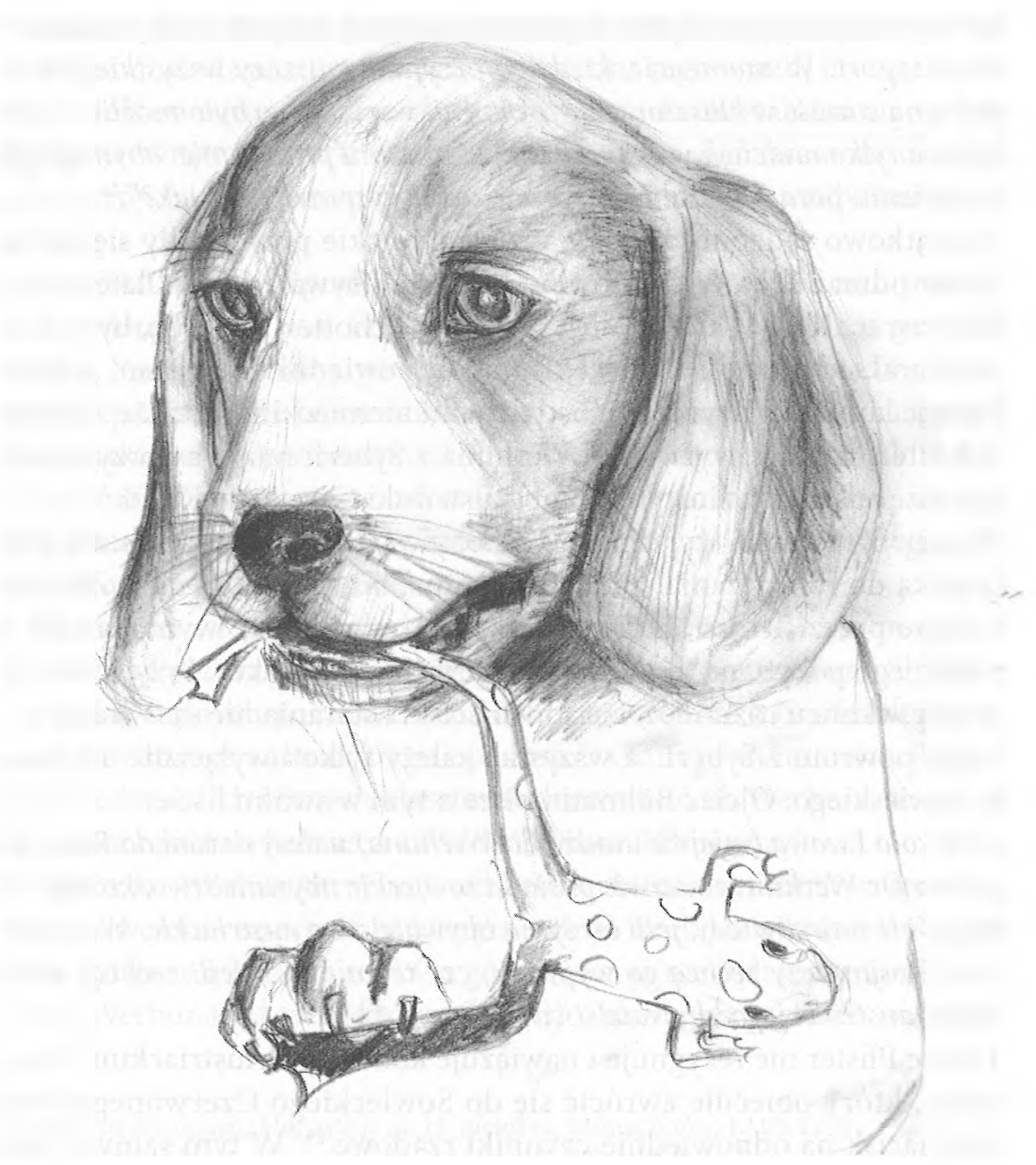

Rys. Sylwester Jauda

30 Arch. Kloster Niederaltaich, Bölmann do Pfistera, Wiedeń, 11.03.1957. Por. Pfister do o. Johannesa, Niederaltaich, 16.03.1957, Buczko do Heufeldera, nr RZ/162?57, Rzym, 17.04.1957. 